\title{
Analysis of Circulating Tumor Cells in Breast Cancer
}

\author{
Zeynep Eroglu, MDa ${ }^{a}$ Odicie Fielder, MDa ${ }^{a}$, and George Somlo, MDa,b \\ aDepartment of Medical Oncology and Therapeutic Research, City of Hope Cancer Center, \\ Duarte, California. \\ ${ }^{b}$ Department of Hematology and Hematopoietic Cell Transplantation, City of Hope Cancer \\ Center, Duarte, California.
}

\begin{abstract}
Over the past few decades, substantial progress has been made in the diagnosis and treatment of breast cancer. Early identification of relapsed and metastatic disease has been a primary focus of ongoing research. Circulating tumor cells (CTCs) are implicated as harbingers of metastases. With advances in detection technologies, CTCs offer the option for real-time liquid biopsies. Methods to identify CTCs in the bloodstream by physical or biochemical properties, although feasible, still require improvements to promote widespread, reproducible use. Sufficient data support enumeration and assessment of changes in the number of CTCs as prognostic indicators, but controversy around their predictive utility for selecting treatments remains. As the technology to detect CTCs and characterize their heterogeneous molecular profile evolves, additional information will likely be obtained to guide targeted and individualized therapies.
\end{abstract}

Through coordinated scientific, medical, and public health advances, 5-year survival rates for breast cancer approach $90 \%$. However, microscopic residual disease frequently results in local relapse or metastasis, leading to approximately 40,000 breast cancer deaths annually in the United States. ${ }^{1}$ Circulatory spread of tumor cells was recognized in the 1800 s. $^{2}$ These circulating tumor cells (CTCs) are thought to be a subpopulation detached from the primary or metastatic tumor sites, and reflect the heterogeneous characteristics of their source. Concentrations of these cells are estimated at as low as 1 CTC per billion normal blood cells. The ability to detect and evaluate the relevance of CTCs has greatly advanced since their initial identification, leading to ongoing exploration of their prognostic and predictive clinical applicability.

\section{Identification of CTCs}

Because of their usually low concentrations, identifying CTCs often requires enrichment. Technologies under assessment may rely on physical characteristics (size, cell density, electric properties, deformability), but more commonly, immunomagnetic separation and immunofluorescence/enzyme-linked immunosorbent assay-based assays are being applied.

(C) JNCCN_Journal of the National Comprehensive Cancer Network

Correspondence: George Somlo, MD, City of Hope Cancer Center, 1500 East Duarte Road, Duarte, CA 91010. gsomlo@ coh.org.

The authors have disclosed that they have no financial interests, arrangements, affiliations, or commercial interests with the manufacturers of any products discussed in this article or their competitors. 
Detection through surface protein expression (the most common being EpCAM) and mRNA/reverse transcription polymerase chain reaction (RT-PCR) assays have also been studied. ${ }^{3}$ In the setting of breast cancer, positive and negative biomarkers such as CD45, MUC-1, GA 73302, cytokeratins, and mammaglobin have been used for immunohistochemically based analysis. ${ }^{4},{ }^{5}$ Studies of the different breast cancer cell subtypes (luminal, basal-like, normal-like, and HER2 ${ }^{+}$) have shown variable EpCAM expression levels, and low/lack of EpCAM expression in the normal-like subtype. ${ }^{6}$ It is hypothesized that epithelial-to-mesenchymal transition (EMT), a process of cell dedifferentiation and loss of cell-cell contact and migration, during which cells lose their epithelial markers (EpCAM, E-cadherin) and take on mesenchymal markers, may be partly responsible for the heterogeneity among CTCs. ${ }^{7}$

The only currently FDA-approved method for detecting CTCs is the CellSearch CTC Test (Veridex, Rarita, NJ), composed of an epithelial kit and cell spotter analyzer. From $7.5 \mathrm{~mL}$ of blood, anti-EpCAM antibodies are applied to immunomagnetically enrich and fluorescently label CTCs. Cytokeratin antibodies further distinguish between white blood cells, which express CD45, and carcinoma cells (markers including CK8, CK18, and CK19). Cells with phenotype CK8/18/19+ and CD45- are counted as CTCs. ${ }^{8}$ Nuclear staining uses 4'-6-Diamidino-2-phenylindole (DAPI). Limitations of this technology include the inability to recognize cells with low expression of EpCAM. Broadening the cytokeratin spectrum may improve detection of CTCs and reduce false-negatives. ${ }^{9}$ The technology does allow for limited scope phenotypic estrogen receptor (ER) and HER2 analysis.

An alternative method is the AdnaTest Breast-Cancer Select system (AdnaGen, Langenhagen, Germany), which uses immunomagnetic beads coated with epithelial surface antigens (surface glycoprotein GA-773 2, HER2, or MUC-1). After detection of an antigen and isolation of mRNA with RT-PCR, the number of CTCs is indirectly determined. This test may allow for increased sensitivity over the CellSearch assay, with CTC detection rates ranging from $69 \%$ to $73 \%,{ }^{10},{ }^{11}$ but it has not yet gained FDA approval. Testing a larger volume of blood with CellSearch can increase the yield of CTCs, but this is not practical, and when the criteria for defining a CTC is loosened, its association with survival seems to decrease. $^{12}$

Additional and evolving CTC detection methods include microchip technology, leukapheresis, fluorescence-activated cell sorting, fluorescence cytometry, cell culture with identification of MUC-1 and CK-19, and laser scanning cytometry. ${ }^{3},{ }^{13}$ Although microchip technology was originally described using silicon champers with EpCAM antibody-coated microposts, ${ }^{14}$ newer assays are being developed that detect EpCAM-negative CTCs. ${ }^{15}$ Ongoing studies are also evaluating circulating microRNAs in plasma to predict the presence of CTCs. ${ }^{16}$

\section{Prognostic and Predictive Value of CTC Detection Early-Stage Breast Cancer}

Detection and enumeration of CTCs have not been translated into clinical utility primarily because of the lack of predictive value. The 2007 ASCO tumor marker guidelines stated that 
measurement of CTCs should not be used for diagnosis or treatment modifications. ${ }^{17}$ Although the CellSearch system cutoff of 5 or greater CTCs per $7.5 \mathrm{~mL}$ of blood has been validated in metastatic breast cancer, isolation of a single cell ( $\geq 1$ CTC per $7.5 \mathrm{~mL}$ of blood) has been considered the cutoff for CTC positivity in early-stage breast cancer.

Differentiating between cells that play a role in spreading viable tumor deposits versus those which are biologically inert requires ongoing efforts. Numerous studies have been conducted of CTCs and survival in early-stage breast cancer (Table 1). ${ }^{18}{ }^{20}$ Two recent studies of patients with stage I-III breast cancer found that the presence of 1 or more CTCs per $7.5 \mathrm{~mL}$ of blood predicted shorter progression-free and overall survivals, and 1 or more CTC detected before initiating neoadjuvant chemotherapy adversely affected distant metastasis-free and overall survivals. ${ }^{21},{ }^{22}$ In a meta-analysis of 49 studies enrolling 6825 patients in both early-stage and metastatic breast cancer settings, ${ }^{23}$ the presence of CTCs in early-stage breast cancer was associated with an increased risk of disease recurrence (hazard ratio $[\mathrm{HR}], 2.86)$ and death $(\mathrm{HR}, 2.78)$ regardless of detection method or time point of blood withdrawal. Elimination of CK-19 mRNA-positive CTCs during adjuvant chemotherapy was also found to be an indicator of treatment efficacy and favorable clinical outcome. ${ }^{24}$

\section{Metastatic Breast Cancer}

CTCs have been found using the CellSearch CTC Test in approximately $60 \%$ of patients with metastatic breast cancer, ${ }^{25}{ }^{27}$ with higher numbers noted in those with multiple bone metastases. ${ }^{28}$ In a retrospective analysis of 151 patients with metastatic breast cancer, baseline CTC levels of 5 or greater CTCs per $7.5 \mathrm{~mL}$ of blood using CellSearch were prognostic for decreased progression-free and overall survivals (from 29.3 to 13.5 months; Table 2 shows selected studies). ${ }^{29}$ Another study of 74 patients also found a significant correlation between CTC levels and radiographic disease progression. ${ }^{30} \mathrm{~A}$ nomogram based on number of CTCs at baseline and other characteristics has been developed to determine the probability of overall survival at 1,2, and 5 years in patients with metastatic breast cancer starting first-line chemotherapy. ${ }^{31}$

In a prospective study of 177 patients with metastatic breast cancer, CTC levels checked at any time during the course of treatment correctly predicted the clinical outcome. ${ }^{25}$ Patients who converted from 5 or greater CTCs to fewer than 5 CTCs per $7.5 \mathrm{~mL}$ of blood experienced progression-free and overall survivals comparable to those of patients whose CTCs were never elevated. Of 177 patients, 138 underwent imaging studies at baseline and throughout treatment. The median overall survival of patients without radiologic progression and 5 or greater CTCs was significantly shorter than that of patients with radiologic progression and fewer than 5 CTCs (15.3 vs 26.9 months), whereas the median overall survival of patients with radiologic progression and fewer than 5 CTCs was significantly longer than patients with 5 or greater CTCs and radiologic progression (19.9 vs 6.4 months). ${ }^{26}$

The prognostic value of CTCs was also compared with that of serum tumor markers in 267 patients with metastatic breast cancer treated with first-line chemotherapy. ${ }^{27} \mathrm{CTC}$ counts of 5 or greater CTCs per $7.5 \mathrm{~mL}$ of blood at baseline were a strong prognostic factor for progression-free and overall survivals. Half of those patients had 5 or greater CTCs per 7.5 
$\mathrm{mL}$ of blood at cycle 2, and changes were correlated with both progression-free and overall survivals, although neither tumor makers nor CTC changes between baseline and cycle 2 were associated with tumor response. At tumor progression, only CTC counts of 5 or greater per $7.5 \mathrm{~mL}$ of blood were prognostic for overall survival. ${ }^{32}$ In the meta-analysis mentioned earlier, the prognostic value of CTCs in patients with metastatic breast cancer was significant for both progression-free survival (HR, 1.78) and overall survival (HR, 2.33). ${ }^{23}$ CTCs detected before, during, and after systemic therapy all had comparable prognostic values. However, the effects of therapy on the prognostic value of CTCs could not be evaluated in the meta-analysis given the different treatment regimens used in the analyzed studies.

To further assess the utility of therapy decisions based on CTCs, SWOG designed a randomized phase III study on metastatic breast cancer patients using CellSearch, with results pending (ClinicalTrials.gov identifier: NCT00382018). Patients with 5 or greater CTCs after 1 cycle were randomized to either continue with current chemotherapy until progression or switch to a different regimen. Primary outcome measures include whether progression-free and overall survivals improve after changing to an alternative chemotherapy regimen based on CTCs, and the prognostic value of sequentially collected CTC values. Although the SWOG study is assessing first-line treatment, the ongoing phase III French CirCe01 study is focusing on the third and subsequent lines of treatment for patients with metastatic breast cancer, with the primary outcome of overall survival (ClinicalTrials.gov identifier: NCT01349842).

\section{In HER2+ Breast Cancer}

A study of patients with metastatic breast cancer using CellSearch and CTC-chip platforms found CTC counts to be lower in patients with HER2 ${ }^{+}$triple-negative breast cancer than in those with $\mathrm{ER}^{+}$breast cancer. ${ }^{33}$ The investigators hypothesized that this may be from low EpCAM expression and a higher percentage of EMT-associated phenotype of tumors in the basal-like molecular subtypes. In a retrospective analysis of 517 patients with metastatic breast cancer, Giordano et al ${ }^{34}$ analyzed the relationship between baseline CTCs and breast tumor subtypes. The median overall survival for patients with fewer than 5 and 5 or greater CTCs were 32.4 and 18.3 months, and the median overall and progression-free survivals were significantly shorter in patients with $\mathrm{ER}^{+} / \mathrm{HER}^{-}$breast cancer with 5 or greater CTCs than in those with fewer than 5 CTCs. However, no significant difference was seen in median overall survival in patients with $\mathrm{HER} 2^{+} / \mathrm{ER}^{-}$breast cancer with 5 or greater CTCs versus those with fewer than 5 CTCs. CTCs seemed to have the most prognostic value in $\mathrm{ER}^{+}$and triple-negative breast cancers, and the least value in patients with $\mathrm{HER}_{2}{ }^{+}$breast cancer treated with HER2-targeted therapy. Several studies have shown that HER2-targeting drugs have a substantial effect in decreasing CTC counts. ${ }^{27}, 35$ Because $83 \%$ of the patients with HER $2^{+}$metastatic breast cancer in the study by Giordano et $\mathrm{al}^{34}$ had received HER2targeted treatments, the authors hypothesized that trastuzumab and lapatinib may have "removed" most circulating cells that overexpress HER2 from circulation, thus reducing the prognostic value of CTC enumeration. ${ }^{34}$ Lack of prognostic value of CTCs in patients with metastatic breast cancer receiving HER2-targeted therapies was also seen in other studies. ${ }^{36},{ }^{37}$ CTC detection did predict overall survival associated with HER2 ${ }^{+}$status in a 
study of 468 patients with metastatic breast cancer, but only in those who had not been treated with trastuzumab. ${ }^{38} \mathrm{CTC}$ in response to trastuzumab and lapatinib were also analyzed in the neoadjuvant setting in the phase III Neo-ALTTO trial. ${ }^{39}$ No significant correlation was seen between CTC detection at any point and pathologic complete response or FDG-PET/CT scan response.

As an adjunct to detecting HER2 overexpression in tumor biopsies, a different approach has been the evaluation of HER2 expression in the CTCs using immunohistochemistry or fluorescence in situ hybridization. Discordance in HER2 status between tumors biopsies and CTCs from the same patients was reported in several studies, with $23 \%$ to $39 \%$ of patients with HER2 ${ }^{-}$primary breast cancers found to have HER2 ${ }^{+}$CTCs. ${ }^{40}{ }^{42}$ The adjuvant phase III SUCCESS-B trial of early HER $2^{+}$breast cancer assessed baseline CTCs; patients were considered to have HER2 ${ }^{+}$CTCs if they had 1 or more detectable CTC with strong staining. ${ }^{43}$ Results showed a discordance similar to that seen in other studies; of the 257 patients with HER $2^{+}$breast cancer with detectable CTCs, only $57.2 \%$ were determined to have HER $2^{+}$CTCs and $21.4 \%$ were questionable (having moderate HER2 staining). Data are pending on survival and the potential role of HER2 ${ }^{+} \mathrm{CTCs}$ in determining treatment efficacy. Another study assessed the prognostic value of HER $2^{+}$CTCs in patients with metastatic breast cancer starting a new line of treatment. ${ }^{44}$ At first follow-up, patients with HER $2^{+}$CTCs (who may have had HER $2^{+}$or HER $2^{-}$primary tumors) had significantly shorter progression-free and overall survivals than those without HER2 ${ }^{+}$CTCs.

The utility of using anti-HER2 therapy in patients with HER2 ${ }^{-}$primary tumors and HER2 ${ }^{+}$ CTCs was tested in a phase II study of patients with metastatic breast cancer given lapatinib. ${ }^{45}$ Among the 7 of 96 patients who had HER $2^{+}$CTCs who were eligible and treated with lapatinib, no objective tumor responses were seen. The premise of HER2targeted therapy based on CTC expression alone is under investigation in the larger ongoing phase III DEFECT III trial, which is randomizing patients with initially HER2 ${ }^{-}$metastatic breast cancer and HER2 ${ }^{+}$CTCs to standard therapy with or without lapatinib (ClinicalTrials.gov identifier: NCT01619111).

\section{Molecular Profiling of CTCs}

Besides enumeration, substantial interest has been shown in molecular characterization of CTCs. Drug-resistance profile has been explored through studying the expression of ATPbinding cassette transporters, which include multidrug resistance-related proteins (MRPs) that transport chemotherapeutics out of cancer cells. ${ }^{46}$ Irrespective of tumor type and stage of disease, expression of MRPs on CTCs was observed to be predictive of resistance to chemotherapy in one trial. ${ }^{46}$ Another study evaluated CTCs from 42 patients with metastatic breast cancer for the expression of MRPs and aldehyde dehydrogenase 1 (ALDH1, a marker of breast cancer stem cells). ${ }^{47}$ Of the 19 patients with drug resistance CTC profiles, $15 \mathrm{had}$ progressive disease, whereas all 9 with drug sensitivity profiles had stable disease or partial/ complete responses. Patients whose CTCs expressed MRPs had a significantly shorter progression-free survival than those without (7.05 vs 16.44 months), suggesting that MRP overexpression on CTCs may predict poor response to specific chemotherapeutics. A significant correlation was also seen between MRPs expressed in CTCs and ALDH1, with 
this second marker more prevalent in HER2 ${ }^{+}$CTCs. Yet another trial of patients with metastatic breast cancer found that the percentage of ALDH1-high-expressing CTCs increased after chemotherapy, suggesting that CTCs that either possess or acquire stem cell features are more resistant to chemotherapy. ${ }^{48}$

Studies have suggested that cancer stem cell (CSC)-like cells may evolve de novo from more differentiated cell types, and that CTCs may also undergo bidirectional interconversions between stem and nonstem compartments. ${ }^{49}$ EMT has been proposed to be involved in the migration and dissemination of cancer cells. A prospective study of patients with HER2 ${ }^{+}$metastatic breast cancer found that patients with EMT-inducing transcription factors in CTCs had more ALDH ${ }^{+}$CSC-like cells. ${ }^{50}$ Whether EMT-CTCs have prognostic value in patients with HER2 ${ }^{+}$metastatic breast cancer treated with HER2-targeted therapy is unknown. In one study, in a subset of 11 patients, an association was observed between the presence of mesenchymal CTCs and breast cancer progression, and between reversible shifts in EMT characteristics and response to therapy. Regulators of EMT including FOXC1 transcription factor and components of transforming growth factor (TGF) $\beta$ pathways were expressed in mesenchymal CTCs. ${ }^{51}$

CTCs with CSC-like features could also provide opportunities for novel targeting strategies, especially in patients with triple-negative breast cancer with or without BRCA mutations/ silencing and with sensitivity to DNA damaging agents, such as platinum compounds. In these settings, testing for platinum-resistance markers may be useful. For example, the excision repair cross-complementation group 1 (ERCC1) enzyme removes cisplatin-induced DNA adducts. Low expression of ERCC1 on CTCs of patients with metastatic non-small cell lung cancer correlates with increased progression-free survival in those who received platinum chemotherapy. ${ }^{52},{ }^{53}$ ERCC 1 testing could also be pursued in breast cancers, because CTC-based selection of chemotherapy regimens could potentially be incorporated into treatment planning. ${ }^{40}$

In addition, testing for drug resistance markers and CSC-like features and for expression of epidermal growth factor receptor (EGFR), phosphorylated EGFR, and members of downstream signal transduction pathways such as PI3K and phospho-AKT expression has also been studied in CTCs of patients with early-stage and metastatic breast cancers. The molecular characteristics may vary between the primary tumors and CTCs. ${ }^{54} \mathrm{~A}$ clonal mutation analysis on CTCs performed in a study of 40 patients with metastatic breast cancer detected mutations of PIK3CA, STK11, and NRAS, with plans to compare the mutational profile between CTCs and primary/metastatic tumors. ${ }^{55}$

While awaiting further development of targeting agents, the high prevalence and significance of the $p 53$ mutation, especially in triple-negative breast cancer, presents a potential for therapeutic intervention. Accordingly, $p 53$ mutations were identified via whole genome amplification through extracting DNA from single CTCs in a pilot trial, and the findings suggested variable mutations and a high prevalence in CTCs. ${ }^{56}$

Attempts are ongoing to identify additional prognostic and potentially targetable markers. CTCs from patients with breast cancer using immunomagnetic enrichment reveal increased 
levels of gene expressions associated with metastasis, such as NPTN, S100A4, and S100A9, and those associated with EMT, such as VIM, TGF 1 , ZEB2, and FOXC1 ${ }^{57}$ A study of 130 patients with metastatic breast cancer before the start of first-line therapy evaluating mRNA gene expression levels in relation to time-to-treatment switch (TTS) found a 16-gene CTC profile that correlated with TTS or death within 9 months. ${ }^{58}$ Analysis of CTC genome-wide copy number alterations over time has also been described. ${ }^{59}$ Although genomic alterations were preserved in individual patients, new alterations in the course of disease progression were also seen, which may allow for evaluation of genomic events connected with a patient's breast cancer progression. Circulating tumor DNA levels are also under investigation, because they may be better correlated with tumor burden changes than CTCs. ${ }^{60}$

\section{Conclusions}

Enumeration of CTCs has been shown in numerous studies to have prognostic value for progression-free and overall survivals in both early-stage and metastatic breast cancers. However, the value of CTCs as predictive markers for treatment outcomes associated with either chemotherapy or targeted therapies is still not completely clear; ongoing clinical trials may provide more conclusive answers. Difficulty obtaining CTCs from peripheral blood, different techniques used for CTC enumeration, and analyses using EpCAM-only-based systems have provided additional challenges. Given further advances in molecular analysis of CTCs, these cells may become guiding targets for personalized therapeutic interventions, because they present or acquire differing genotypes and phenotypes compared with primary and metastatic tumors, and may provide additional real-time information on tumor biology and drug resistance.

\section{Acknowledgments}

Research reported in this publication was supported by National Cancer Institute of the National Institutes of Health under grant number P30CA033572. The content is solely the responsibility of the authors and does not necessarily represent the official views of the National Institutes of Health.

\section{References}

1. Siegel R, Naishadham D, Jemal A. Cancer Statistics, 2012. CA Cancer J Clin. 2012; 62:10-29. [PubMed: 22237781]

2. Ashworth TR. A case of cancer in which cells similar to those in the tumours were seen in the blood after death. Aus Med J. 1869; 14:146-149.

3. Hsieh, HB.; Somlo, G.; Liu, X., et al. Location and biomarker characterization of circulating tumor cells. In: Herold, K.; Rasooly, A., editors. Biosensors and Molecular Technologies for Cancer Diagnostics. Boca Raton, FL: CRC Press; 2012. p. 257-275.

4. Gerber B, Krause A, Muller H, et al. Simultaneous immunohistochemical detection of tumor cells in lymph node and bone marrow aspirates in breast cancer and its correlation with other prognostic factors. J Clin Oncol. 2001; 19:960-971. [PubMed: 11181658]

5. Pantel K, Schlimok G, Angstwurm M, et al. Methodological analysis of immunohistochemical screening for disseminated epithelial tumor cells in bone marrow. J Hematother. 1994; 3:165-173. [PubMed: 7530132]

6. Sieuwerts AM, Kraan J, Bolt J, et al. Anti-epithelial cell adhesion molecule antibodies and the detection of circulating normal-like breast tumor cells. J Natl Cancer Inst. 2009; 101:61-66. [PubMed: 19116383] 
7. Kasimir-Bauer S, Hoffmann O, Wallwiener D, et al. Expression of stem cell and epithelialmesenchymal transition markers in primary breast cancer patients with circulating tumor cells. Breast Cancer Res. 2012; 14:R15. [PubMed: 22264265]

8. Riethdorf S, Fritsche H, Muller V, et al. Detection of circulating tumor cells in peripheral blood of patients with metastatic breast cancer: a validation study of the CellSearch system. Clin Cancer Res. 2007; 13:920-928. [PubMed: 17289886]

9. Joosse S, Hannemann J, Spötter J, et al. Changes in keratin expression during metastatic progression of breast cancer: impact on detection of circulating tumor cells. Clin Cancer Res. 2012; 18:9931003. [PubMed: 22228641]

10. Ross J, Slodlowska EA. Circulating and disseminated tumor cells in the management of breast cancer. Am J Clin Pathol. 2009; 132:237-245. [PubMed: 19605818]

11. Fehm T, Hoffmann O, Aktas B, et al. Detection and characterization of circulating tumor cells in blood of primary breast cancer patients by RT-PCR and comparison to status of bone marrow disseminated cells. Breast Cancer Res. 2009; 11:R59. [PubMed: 19664291]

12. Coumans F, Ligthart S, Uhr J, et al. Challenges in the enumeration and phenotyping of CTC. Clin Cancer Res. 2012; 18:5711-5718. [PubMed: 23014524]

13. Eifler RL, Lind J, Falkenhagen D, et al. Enrichment of circulating tumor cells from a large blood volume using leukapheresis and elutriation: proof of concept. Cytometry B Clin Cytom. 2011; 80:100-111. [PubMed: 20954267]

14. Yu M, Stott S, Toner M, et al. Circulating tumor cells: approaches to isolation and characterization. J Cell Bio. 2011; 192:373-382. [PubMed: 21300848]

15. Mikolajczyk SD, Millar LS, Tsinberg D, et al. Detection of EpCAM negative and cytokeratin negative circulating tumor cells in peripheral blood. J Oncol. 2011; 2011:252361. [PubMed: 21577258]

16. Madhavan D, Zucknick M, Wallwiener M, et al. Circulating miRNAs as surrogate markers for circulating tumor cells and prognostic markers in metastatic breast cancer. Clin Cancer Res. 2012; 18:5972-5982. [PubMed: 22952344]

17. Harris L, Fritsche H, Mennel R, et al. American Society of Clinical Oncology 2007 update of recommendations for the use of tumor markers in breast cancer. J Clin Oncol. 2007; 25:52875312. [PubMed: 17954709]

18. Stathopoulou A, Vlachonikolis I, Mavroudis D, et al. Molecular detection of cytokeratin-19positive cells in the peripheral blood of patients with operable breast cancer: evaluation of their prognostic significance. J Clin Oncol. 2002; 20:3404-3412. [PubMed: 12177100]

19. Xenidis N, Perraki M, Kafousi M, et al. Predictive and prognostic value of peripheral blood cytokeratin 19 mRNA positive cells detected by real time polymerase chain reaction in node negative breast cancer patients. J Clin Oncol. 2006; 24:3756-3762. [PubMed: 16769987]

20. Pierga JY, Bidard FC, Mathiot C, et al. Circulating tumor cell detection predicts early metastatic relapse after neoadjuvant chemotherapy in large operable and locally advanced breast cancer in a phase II randomized trial. Clin Cancer Res. 2008; 14:7004-7010. [PubMed: 18980996]

21. Lucci A, Hall CS, Lodhi AK, et al. Circulating tumour cells in nonmetastatic breast cancer: a prospective study. Lancet Oncol. 2012; 13:688-695. [PubMed: 22677156]

22. Bidard FC, Delaloge S, Giacchetti S, et al. Long term independent prognostic impact of circulating tumor cells detected before neoadjuvant chemotherapy in non-metastatic breast cancer: 70 months analysis of the REMAGUS02 study [abstract]. Cancer Res. 2012; 72(24 Suppl) Abstract P2-01-04.

23. Zhang L, Riethdorf S, Wu G, et al. Meta-analysis of the prognostic value of circulating tumor cells in breast cancer. Clin Cancer Res. 2012; 18:5701-5710. [PubMed: 22908097]

24. Xenidis N, Perraki M, Apostolaki S, et al. Differential effect of adjuvant taxane-based and taxanefree chemotherapy regimens on the CK-19 mRNA-positive circulating tumour cells in patients with early breast cancer. Br J Cancer. 2013; 108:549-556. [PubMed: 23329233]

25. Hayes DF, Cristofanilli M, Budd GT, et al. Circulating tumor cells at each follow up time point during therapy of metastatic breast cancer patients predict progression free and overall survival. Clin Cancer Res. 2006; 12:4218-4224. [PubMed: 16857794] 
26. Budd GT, Cristofanilli M, Ellis MJ, et al. Circulating tumor cells versus imaging - predicting overall survival in metastatic breast cancer. Clin Cancer Res. 2006; 12:6403-6409. [PubMed: 17085652]

27. Pierga JY, Hajage D, Bachelot T, et al. High independent prognostic and predictive value of circulating tumor cells compared with serum tumor markers in a large prospective trial in first-line chemotherapy for metastatic breast cancer patients. Ann Oncol. 2012; 23:618-624. [PubMed: 21642515]

28. De Giorgi U, Valero V, Rohren E, et al. Circulating tumor cells and bone metastases as detected by FDG-PET/CT in patients with metastatic breast cancer. Ann Oncol. 2010; 21:33-39. [PubMed: 19602564]

29. Cristofanilli M, Broglio KR, Guarneri V, et al. Circulating tumor cells in metastatic breast cancer: biologic staging beyond tumor burden. Clin Breast Cancer. 2007; 7:471-479. [PubMed: 17386124]

30. Liu MC, Shields PG, Warren RD, et al. Circulating tumor cells: a useful predictor of treatment efficacy in metastatic breast cancer. J Clin Oncol. 2009; 27:5153-5159. [PubMed: 19752342]

31. Giordano A, Egleston BL, Hajage D, et al. Establishment and validation of circulating tumor cellbased prognostic nomograms in first-line metastatic breast cancer patients. Clin Cancer Res. 2013; 19:1596-1602. [PubMed: 23340302]

32. Pierga JY, Hajage D, Bachelot T, et al. Prognostic value of circulating tumor cells count at progressive disease after first line chemotherapy metastatic breast patients in a large prospective multicenter trial including serum tumor markers (IC 2006-04 study) [abstract]. Cancer Res. 2012; 72(24 Suppl) Abstract P2-01-13.

33. Punnoose EA, Atwal SK, Spoerke JM, et al. Molecular biomarker analyses using circulating tumor cells. PLoS One. 2010; 5:e1251.

34. Giordano A, Giuliano M, De Laurentis M, et al. Circulating tumor cells in immunohistochemical subtypes of metastatic breast cancer: lack of prediction in HER2-positive disease treated with targeted therapy. Ann Oncol. 2012; 23:1144-1150. [PubMed: 21965473]

35. Giuliano M, Giordano A, Jackson S, et al. Circulating tumor cells as prognostic and predictive markers in metastatic breast cancer patients receiving frst-line systemic treatment. Breast Cancer Res. 2011; 13:R67. [PubMed: 21699723]

36. Munzone E, Botteri E, Sandri MT, et al. Prognostic value of circulating tumor cells according to immunohistochemically defined molecular subtypes in advanced breast cancer. Clin Breast Cancer. 2012; 12:340-346. [PubMed: 23040002]

37. Giordano A, Barnato S, Giuliano M, et al. Effect of targeted therapy on circulating tumor cells in patients with metastatic breast cancer [abstract]. J Clin Oncol. 2012; 30(Suppl) Abstract 3.

38. Wallwiener M, Hartkopf A, Baccelli I, et al. The prognostic impact of circulating tumor cells in subtypes of metastatic breast cancer. Breast Cancer Res Treat. 2013; 137:503-510. [PubMed: 23271327]

39. Azim HA Jr, Rothe F, Aura CM, et al. Correlation between circulating tumor cells (CTCs), PET/CT response and pathological and complete response (pCR) in primary HER2-positive (HER2+) breast cancer patients: a substudy from the NeoALTTO trial [abstract]. Ann Oncol. 2012; 23(Suppl 9) Abstract 2467.

40. Somlo G, Lau SK, Frankel P, et al. Multiple biomarker expression on circulating tumor cells in comparison to tumor tissues from primary and metastatic sites in patients with locally advanced/ inflammatory, and stage IV breast cancer, using a novel detection technology. Breast Cancer Res Treat. 2011; 128:155-163. [PubMed: 21499685]

41. Pestrin M, Bessi S, Galardi F, et al. Correlation of HER2 status between primary tumors and corresponding circulating tumor cells in advanced breast cancer patients. Breast Cancer Res Treat. 2009; 118:523-530. [PubMed: 19597704]

42. Fehm T, Becker S, Duerr-Stoerzer S, et al. Determination of HER2 status using both serum HER2 levels and circulating tumor cells in patients with recurrent breast cancer whose primary tumor was HER2 negative or of unknown HER2 status. Breast Cancer Res. 2007; 9:R74. [PubMed: 17963511] 
43. Jaeger B, Rack B, Neugebauer J, et al. HER2 expression on circulating tumor cells (CTC) in patients with early HER2-positive breast cancer: results of the German SUCCESS B trial [abstract]. J Clin Oncol. 2012; 30(Suppl) Abstract 10540.

44. Hayashi N, Nakamura S, Tokuda Y, et al. Prognostic value of HER2-positive circulating tumor cells in patients with metastatic breast cancer. Int J Clin Oncol. 2012; 17:96-104. [PubMed: 21671160]

45. Pestrin M, Bessi S, Puglisi F, et al. Final results of a multicenter phase II clinical trial evaluating the activity of single-agent lapatinib in patients with HER2-negative metastatic breast cancer and HER2-positive circulating tumor cells. A proof-of-concept study. Breast Cancer Res Treat. 2012; 134:283-289. [PubMed: 22476856]

46. Gazzaniga P, Naso G, Gradilone A, et al. Chemosensitivity profile assay of circulating cancer cells (CTCs): prognostic and predictive value in epithelial tumors. Int J Cancer. 2010; 126:2437-2447. [PubMed: 19821489]

47. Gradilone A, Naso G, Raimondi C, et al. Circulating tumor cells (CTCs) in metastatic breast cancer (MBC): prognosis, drug resistance and phenotypic characterization. Ann Oncol. 2011; 22:86-92. [PubMed: 20603432]

48. Papadaki MA, Kallergi G, Mavroudis D, et al. Effect of first-line chemotherapy in the expression of stemness and epithelial-to-mesenchymal transition markers in circulating tumor cells of patients with metastatic breast cancer [abstract]. Cancer Res. 2012; 72(24 Suppl) Abstract P2-01-07.

49. Chaffer CL, Brueckmann I, Scheel C, et al. Normal and neoplastic nonstem cells can spontaneously convert to a stem-like state. Proc Natl Acad Sci U S A. 2011; 108:7950-7955. [PubMed: 21498687]

50. Giordano A, Gao H, Anfossi S, et al. Epithelial-mesenchymal transition and stem cell markers in patients with HER2-positive metastatic breast cancer. Mol Cancer Ther. 2012; 11:2526-2534. [PubMed: 22973057]

51. Yu M, Bardia A, Wittner B, et al. Circulating breast tumor cells exhibit dynamic changes in epithelial and mesenchymal composition. Science. 2013; 339:580-584. [PubMed: 23372014]

52. Olaussen KA, Dunant A, Fouret P, et al. DNA repair by ERCC1 in non-small-cell lung cancer and cisplatin-based adjuvant chemotherapy. N Engl J Med. 2006; 355:983-991. [PubMed: 16957145]

53. Riess J, Das M, Frankel P, et al. Correlation of ERCC1 expression on circulating tumor cells with progression-free survival in metastatic non-small cell lung cancer patients treated with platinumbased chemotherapy [abstract]. J Clin Oncol. 2012; 30(Suppl) Abstract 10574.

54. Kallergi G, Agelaki S, Kalykaki A, et al. Phosphorylated EGFR and PI3K/Akt signaling kinases are expressed in circulating tumor cells of breast cancer patients. Breast Cancer Res. 2008; 10:80.

55. Xu X, Shen Y, Dewitt W, et al. Mutational analysis of circulating tumor cells in breast cancer patients by targeted clonal sequencing [abstract]. J Clin Oncol. 2012; 30(Suppl) Abstract 10516.

56. Yang L, Wang Y, Chu P, et al. Identification of p53 mutation in whole genome DNA from single circulating tumor cells (CTCs) and primary breast cancers (BC) from patients (pts) with metastatic breast cancer (MBC) [abstract]. Cancer Res. 2012; 71(24 Suppl) Abstract P4-07-12.

57. Powell A, Talasaz AH, Zhang H, et al. Single cell profiling of circulating tumor cells: transcriptional heterogeneity and diversity from breast cancer cell lines. PLoS One. 2012; 7:e33788. [PubMed: 22586443]

58. Mostert B, Sieuwerts A, Kraan J, et al. Gene expression profiles of circulating tumor cells in metastatic breast cancer patients [abstract]. J Clin Oncol. 2012; 30(Suppl) Abstract 10504.

59. Magbanua MJ, Sosa EV, Roy R, et al. Genomic profiling of isolated circulating tumor cells from metastatic breast cancer patients. Cancer Res. 2013; 73:30-40. [PubMed: 23135909]

60. Dawson SJ, Tsui D, Murtaza M, et al. Analysis of circulating tumor DNA to monitor metastatic breast cancer. N Engl J Med. 2013; 368:1199-1209. [PubMed: 23484797]

61. Camara O, Rengsberger M, Egbe A, et al. The relevance of circulating epithelial tumor cells (CETC) for therapy monitoring during neoadjuvant (primary systemic) chemotherapy in breast cancer. Ann Oncol. 2007; 18:1484-1492. [PubMed: 17761704]

62. Pachmann K, Camara O, Kavallaris A, et al. Monitoring the response of circulating epithelial tumor cells to adjuvant chemotherapy in breast cancer allows detection of patients at risk of early relapse. J Clin Oncol. 2008; 26:1208-1215. [PubMed: 18323545] 
63. Franken B, de Groot MR, Mastboom WJ, et al. Circulating tumor cells, disease recurrence and survival in newly diagnosed breast cancer. Breast Cancer Res. 2012; 14:R133. [PubMed: 23088337]

64. Muller V, Riethdorf S, Rack B, et al. Prognostic impact of circulating tumor cells assessed with the CellSearch System and AdnaTest Breast in metastatic breast cancer patients: the DETECT study. Breast Cancer Res. 2012; 14:R118. [PubMed: 22894854] 
Table 1

Studies in Early-Stage Breast Cancer

\begin{tabular}{|c|c|c|c|c|}
\hline & $\begin{array}{l}\text { Stage and Time } \\
\text { of CTCs Obtained }\end{array}$ & $\mathbf{N}$ & Detection Method & Outcomes \\
\hline $\begin{array}{l}\text { Stathopoulou et } \\
\text { al, }{ }^{18} 2002\end{array}$ & $\begin{array}{l}\text { Stage I-II } \\
\text { Before adjuvant therapy }\end{array}$ & 148 & RT-PCR (CK-19 mRNA-positive) & $\begin{array}{l}\text { Detected in } 30 \% \text { of patients } \\
\text { Associated with reduced disease-free } \\
\text { interval and overall survival }\end{array}$ \\
\hline $\begin{array}{l}\text { Xenidis et al, }{ }^{19} \\
2006\end{array}$ & $\begin{array}{l}\text { N0 } \\
\text { Before adjuvant therapy }\end{array}$ & 167 & RT-PCR (CK-19 mRNA-positive) & $\begin{array}{l}\text { Detected in } 21.6 \% \text {, associated with } \\
\text { early clinical relapse and disease- } \\
\text { related death }\end{array}$ \\
\hline $\begin{array}{l}\text { Camara et al, }{ }^{61} \\
2007\end{array}$ & $\begin{array}{l}\mathrm{T} 2-\mathrm{T} 4 \\
\text { Before, during, and after } \\
\text { neoadjuvant therapy }\end{array}$ & 58 & $\begin{array}{l}\text { Laser scanning cytometry (epithelial } \\
\text { CTCs) }\end{array}$ & $\begin{array}{l}\text { Decrease of CTCs during the first } \\
\text { cycle of neoadjuvant chemotherapy } \\
\text { predicted the final response of the } \\
\text { tumor }\end{array}$ \\
\hline $\begin{array}{l}\text { Pierga et al, }{ }^{20} \\
2008\end{array}$ & $\begin{array}{l}\text { Stage II-III } \\
\text { Before and after neoadjuvant } \\
\text { therapy }\end{array}$ & 118 & $\begin{array}{l}\text { CellSearch } \\
(\geq 1 \text { CTC/7.5 mL) }\end{array}$ & $\begin{array}{l}\text { Detected in } 23 \% \text { of preneoadjuvant } \\
\text { chemotherapy patients; } 17 \% \text { in } \\
\text { postchemotherapy patients } \\
\text { Not correlated with the primary tumor } \\
\text { response, but a prognostic factor for a } \\
\text { shorter distant metastasis-free survival }\end{array}$ \\
\hline $\begin{array}{l}\text { Pachmann et al, }{ }^{62} \\
2008\end{array}$ & $\begin{array}{l}\text { Stage I-III } \\
\text { Before, during, and end of } \\
\text { adjuvant therapy }\end{array}$ & 91 & $\begin{array}{l}\text { Laser scanning cytometry } \\
\text { (circulating epithelial tumor cells) }\end{array}$ & $\begin{array}{l}\text { Increase of } \geq 10 \text {-fold at the end of } \\
\text { therapy predicted relapse-free survival } \\
\text { and a marker for aggressiveness of the } \\
\text { tumor cells }\end{array}$ \\
\hline $\begin{array}{l}\text { Lucci et al, }{ }^{21} \\
2012\end{array}$ & $\begin{array}{l}\text { Stage I-III } \\
\text { Collected at time of surgery }\end{array}$ & 302 & $\begin{array}{l}\text { CellSearch } \\
(\geq 1 \text { CTC/7.5 mL) }\end{array}$ & $\begin{array}{l}\text { Detected in } 24 \% \text { of patients } \\
\text { Predicted both decreased progression- } \\
\text { free and overall survival }\end{array}$ \\
\hline $\begin{array}{l}\text { Bidard et al, }{ }^{22} \\
2012\end{array}$ & $\begin{array}{l}\text { Stage I-III } \\
\text { Before and after neoadjuvant } \\
\text { therapy }\end{array}$ & 115 & $\begin{array}{l}\text { CellSearch } \\
(\geq 1 \text { CTC/7.5 mL) }\end{array}$ & $\begin{array}{l}\text { CTC detection before chemotherapy } \\
\text { (in 23\%) prognostic for distant } \\
\text { metastasis-free and overall survivals } \\
\text { At long-term, CTC detection after } \\
\text { chemotherapy (17\%) had no clear } \\
\text { prognostic significance }\end{array}$ \\
\hline $\begin{array}{l}\text { Franken et al, }{ }^{63} \\
2012\end{array}$ & $\begin{array}{l}\text { Stage I-III } \\
\text { Before surgery }\end{array}$ & 404 & $\begin{array}{l}\text { CellSearch } \\
(\geq 1 \mathrm{CTC} / 7.5 \mathrm{~mL})\end{array}$ & $\begin{array}{l}\text { Detected in } 19 \% \text {, associated with } \\
\text { distant disease-free survival, but not } \\
\text { overall }\end{array}$ \\
\hline $\begin{array}{l}\text { Xenidis et al, }{ }^{24} \\
2013\end{array}$ & $\begin{array}{l}\text { Stage I-III } \\
\text { Before and after taxane-free and } \\
\text { taxane-based chemotherapy }\end{array}$ & 545 & RT-PCR (CK-19 mRNA-positive) & $\begin{array}{l}\text { Detected in } 43.5 \% \text { of patients with } \\
\text { detectable CTCs before adjuvant } \\
\text { chemotherapy } \\
\text { Elimination of CTCs during treatment } \\
\text { was associated with favorable clinical } \\
\text { outcome }\end{array}$ \\
\hline
\end{tabular}

Abbreviations: CTC, circulating tumor cell; RT-PCR, reverse transcriptase polymerase chain reaction. 
Table 2

Studies in Metastatic Breast Cancer

\begin{tabular}{|c|c|c|c|c|}
\hline & Time CTCs Obtained & $\mathbf{N}$ & $\begin{array}{l}\text { Detection } \\
\text { Method }\end{array}$ & Outcomes \\
\hline $\begin{array}{l}\text { Hayes et al, }{ }^{25} \\
2006\end{array}$ & $\begin{array}{l}\text { At baseline, } 3-5,6-8,9-14 \text {, and } \\
15-20 \text { weeks after initiation of } \\
\text { treatment }\end{array}$ & 177 & $\begin{array}{l}\text { CellSearch } \\
(\geq 5 \text { CTC/7.5 mL) }\end{array}$ & $\begin{array}{l}\text { Detected in } 54 \% \text { of patients in } \geq 1 \text { blood draws } \\
\text { Patients who converted from elevated CTCs to } \\
\text { nonelevated levels had PFS and OS comparable to } \\
\text { those whose CTCs were never elevated }\end{array}$ \\
\hline $\begin{array}{l}\text { Budd et al, }{ }^{26} \\
2006\end{array}$ & $\begin{array}{l}\text { At baseline and approximately } 4 \\
\text { weeks after treatment }\end{array}$ & 138 & $\begin{array}{l}\text { CellSearch } \\
(\geq 5 \mathrm{CTC} / 7.5 \mathrm{~mL})\end{array}$ & $\begin{array}{l}\text { Detected in } 43 \% \text { at baseline } \\
\text { Median OS of patients with radiologic } \\
\text { nonprogression and } 25 \text { CTCs was shorter than that of } \\
\text { patients with radiologic nonprogression and }<5 \text { CTCs } \\
\text { Median OS of patients with radiologic progression } \\
\text { and }<5 \text { CTCs was longer than that of patients with } \geq 5 \\
\text { CTCs and radiologic progression }\end{array}$ \\
\hline $\begin{array}{l}\text { Cristofanilli et } \\
\mathrm{al},{ }^{29} 2007\end{array}$ & $\begin{array}{l}\text { At time of staging and before } \\
\text { starting new treatment }\end{array}$ & 151 & $\begin{array}{l}\text { CellSearch } \\
(\geq 5 \text { CTC/7.5 mL) }\end{array}$ & $\begin{array}{l}\text { Detected in } 44 \% \\
\text { Elevated CTCs were prognostic for decreased PFS } \\
\text { and OS }\end{array}$ \\
\hline Liu et al, ${ }^{30} 2009$ & $\begin{array}{l}\text { At baseline, and at 3- to 4-week } \\
\text { intervals }\end{array}$ & 74 & $\begin{array}{l}\text { CellSearch } \\
(\geq 5 \mathrm{CTC} / 7.5 \mathrm{~mL})\end{array}$ & $\begin{array}{l}\text { Detected in } 35 \% \\
\text { Correlation between CTC levels obtained at time of } \\
\text { imaging, 3-5 before imaging, and 7-9 weeks before } \\
\text { imaging and radiographic disease progression } \\
\text { Shorter PFS in patients with elevated CTCs at 3-5 } \\
\text { and } 7-9 \text { weeks after start of treatment }\end{array}$ \\
\hline $\begin{array}{l}\text { De Giorgi et al, }{ }^{28} \\
2010\end{array}$ & At time of relapse/progression & 195 & $\begin{array}{l}\text { CellSearch } \\
(\geq 5 \mathrm{CTC} / 7.5 \mathrm{~mL})\end{array}$ & $\begin{array}{l}\text { Detected in } 47 \% \\
\text { Increasing number of bone metastases associated } \\
\text { with higher number of CTCs compared with those } \\
\text { with } 1 \text { or } 2 \text {, or no bone metastases }\end{array}$ \\
\hline $\begin{array}{l}\text { Giuliano et al, }{ }^{35} \\
2011\end{array}$ & $\begin{array}{l}\text { Before initiation of systemic } \\
\text { treatment }\end{array}$ & 235 & $\begin{array}{l}\text { CellSearch } \\
(\geq 5 \mathrm{CTC} / 7.5 \mathrm{~mL})\end{array}$ & $\begin{array}{l}\text { Detected in } 40 \% \\
\text { Elevated CTCs prognostic for PFS and OS (except in } \\
\text { patients with HER } 2^{+} \text {breast cancer receiving } \\
\text { trastuzumab or lapatinib, because baseline CTC } \\
\text { count was not prognostic) }\end{array}$ \\
\hline $\begin{array}{l}\text { Pierga et al, }{ }^{27} \\
2012\end{array}$ & $\begin{array}{l}\text { At baseline, before cycle } 2 \text { and } \\
\text { cycle } 3 \text { or } 4 \text { of treatment }\end{array}$ & 267 & $\begin{array}{l}\text { CellSearch } \\
(\geq 5 \text { CTC/7.5 mL) }\end{array}$ & $\begin{array}{l}\text { Detected in } 44 \% \text { at baseline } \\
\text { Elevated CTCs at baseline and cycle } 2 \text { were } \\
\text { prognostic for PFS and OS } \\
\text { CTC changes between baseline and cycle } 2 \text { were not } \\
\text { associated with tumor response }\end{array}$ \\
\hline $\begin{array}{l}\text { Muller et al, }{ }^{64} \\
2012\end{array}$ & Before initiation of new therapy & 254 & $\begin{array}{l}\text { CellSearch } \\
(\geq 5 \text { CTC/7.5 mL) } \\
\text { and AdnaTest }\end{array}$ & $\begin{array}{l}\text { Detected in } 50 \% \text { with CellSearch, prognostic for } \\
\text { overall survival } \\
\text { Detected in } 40 \% \text { with AdnaTest, not associated with } \\
\text { OS }\end{array}$ \\
\hline $\begin{array}{l}\text { Wallwiener et } \\
\text { al, }{ }^{38} 2013\end{array}$ & Before initiation of new therapy & 468 & $\begin{array}{l}\text { CellSearch } \\
(\geq 5 \mathrm{CTC} / 7.5 \mathrm{~mL})\end{array}$ & $\begin{array}{l}\text { Detected in } 42 \% \text { at baseline } \\
\text { CTC positivity was an independent prognostic factor } \\
\text { for shorter PFS and OS }\end{array}$ \\
\hline
\end{tabular}

Abbreviations: CTC, circulating tumor cell; OS, overall survival; PFS, progression-free survival. 